\title{
Prospects for individual economies
}

\section{United States}

Although GDP grew in the first quarter by 3.1 per cent (at an annualised rate), repeating the relatively strong growth seen in the first three quarters of 2018, our expectation continues to be that output growth in the US economy will slow. This was certainly the case in the second quarter, when GDP grew by 2 per cent, with fixed investment falling by 1.4 per cent in the quarter, recording the first quarterly fall since the final quarter of 2015 . With exports also falling, by 5.7 per cent, net trade made a negative contribution to GDP growth.

Our near-term expectation is that the slowing in growth will continue, but that there will not be a substantial downturn in activity. After strong GDP growth of 2.9 per cent in 2018, our forecast is for growth of $2 \frac{1 / 4}{4}$ per cent this year and almost 2 per cent next. To some extent this slowing can be viewed as a return towards trend growth (which we estimate to be around 13/4 per cent) after a period during which growth was boosted by a fiscal stimulus and a prolonged period of ultra-low interest rates. Growth has slowed as the impetus from the stimulus has faded and as the Federal Reserve has pursued a policy of normalisation.

The US economy does, however, show some divergent features. The short-term activity indicators such as the ISM activity indices show industrial production falling in the first two quarters of this year, but service sector activity continuing to increase. The fall in industrial production is part of a wider theme in the global economy, reflecting the effect of tariffs and reduced trade growth, and may also in part reflect safety concerns that have disrupted production at Boeing. This decline has played a part in the recent Federal Reserve decisions to halt and then reverse monetary policy normalisation. Policy interest rate cuts in July and September have marked a faster pace than financial markets were expecting six months ago and our assumption, which is based on market rates, is that there will be another rate cut soon in order to continue to support economic activity.

The 'core' PCE measure of consumer price inflation has been running at just over 1.5 per cent so far this year. There may now be some signs coming through of rises in imported goods prices, which have resulted from the increase in tariffs over the past eighteen months, but this effect is unlikely to be large enough to lead the Federal Reserve to change its policy direction.
Set against the picture of weak industrial production is the continued strength in the labour market. At 3.5 per cent, the unemployment rate is at a 50-year low (as shown in figure 8 )and the key monthly non-farm payroll indicator has continued to rise, although the average monthly increases have been lower this year than last. With a tightening labour market, albeit with a debate about how tight the market really is, there appears to have been little pass-through of pressure onto domestic inflation to date. The forecast projects that the falls in the unemployment rate will halt as slower output growth feeds through and that by 2021 the unemployment rate will have edged up slightly, but still be at an historically low level.

While the forecast is for a slowdown in GDP growth, the issue of whether a US slowdown might develop into a recession has become a topic of debate. While part of the debate has arisen because of the fall in industrial production, part also comes from the fact that the US economy is now in its longest ever recorded economic expansion and in a framework that sees expansions being followed by downturns and recessions, a forward focus is perhaps naturally drawn to the downside risk. At the same time, the spread between long-term and shortterm market interest rates has gradually fallen and in

Figure 8. US: Unemployment rate

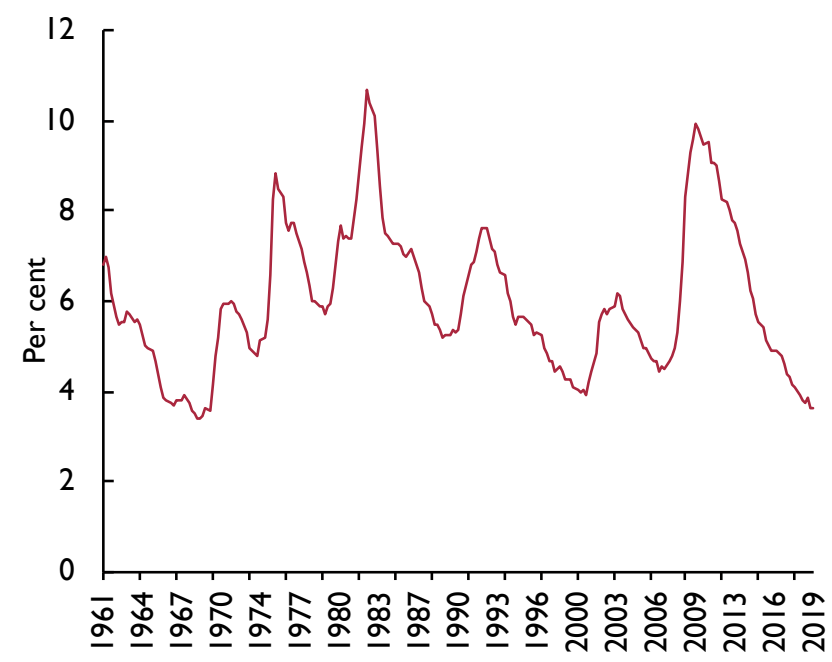

Source: NiGEM database. 
recent months turned negative. Several economic studies have shown that a negative yield spread has proved to be a good indicator of recession one year ahead. The recent falls in the spread have therefore implied a greater probability of a recession in 2020 (Lenoel, 2018, 2019). The New York Federal Reserve's model for this relationship shows, based on data to September, a 35 per cent probability of recession a year ahead. This indicator has been rising for some time and is at the highest reading since 2008 .

The fall in the yield spread has arisen because the 10year Treasury bond yield has fallen consistently from early November last year (when it hit a local peak of 3.24 per cent) to marginally below 1.50 per cent in August this year. The policy rate cut in early September initially appeared to boost confidence and the 10-year yield rose quickly back to 1.90 per cent. It has since, however, fallen back again to stand above 1.70 per cent on 11 October, perhaps reflecting expectations of further policy rate reductions. With the Federal Reserve having been criticised by President Trump for raising rates and not letting the economy 'run hot' at a time when inflation has been below the 2 per cent target, the President has criticised the Federal Reserve for not reducing interest rates further and faster. But the rate reductions that the Federal Reserve has made should bolster economic growth and support our forecast view of a slowdown in growth rather than a recession.

While inflation and inflation expectations remain benign, the Federal Reserve has scope for further policy changes. One risk is that the uncertainty created by the trade wars and the effect of tariff increases on prices might be such that economic activity slows more sharply than anticipated and inflation picks up more than expected. If inflation expectations were to become de-anchored, the policy problem for the Federal Reserve would become even more complex and the downside risks to the economy could materialise.

The unexpected announcement on 10 May by President Trump of a tariff rate of 25 per cent on a further $\$ 200$ billion of imported goods from China, and that tariffs on a further $\$ 300$ billion of imports were also being considered, pushed the trade dispute into new territory. Heightened uncertainty over trade policy may have contributed to reduced US and global business confidence and investment. China is not the only country that has been affected by US tariffs. Imports of steel and aluminium from many countries have been affected, as have external producers of solar panels and washing machines, and the potential imposition of tariffs on
Figure 9. US: Annual GDP growth fan chart

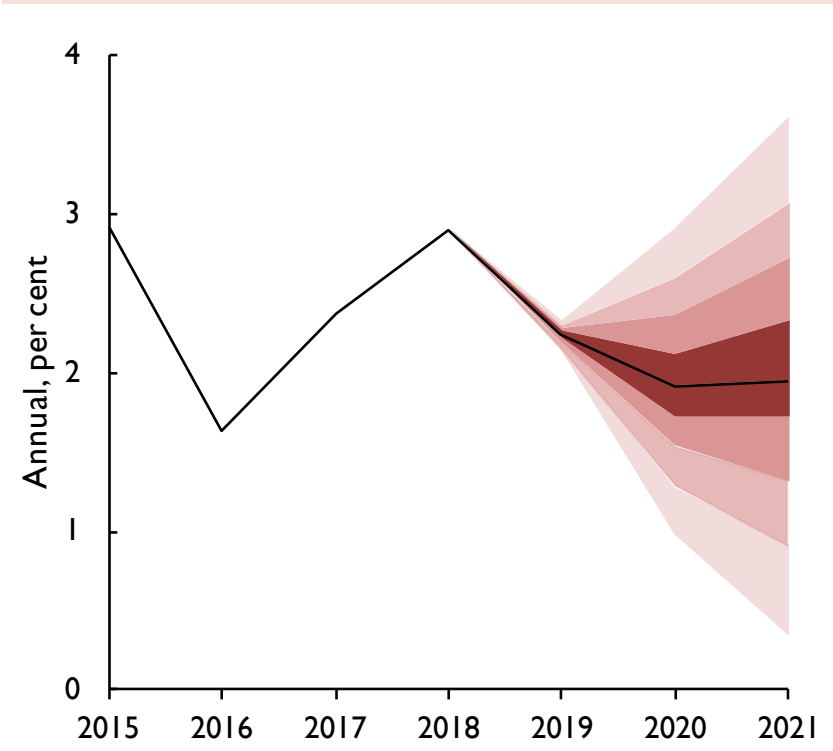

Source: NiGEM database, NIESR forecast and NiGEM stochastic simulations. Notes: The fan chart is intended to represent the uncertainty around the central forecast shown by the central line. There is a 10 per cent chance that GDP growth in any particular year will lie in any given shaded segment in the chart. There is a 20 per cent chance that GDP growth will lie outside the shaded area of the fan.

automobile imports remains a concern to producers in countries such as Mexico, Japan and Germany. The recent ruling from the WTO regarding European Union support for Airbus has meant that the subject of further tariffs has remained in the news, adding to the uncertainty about the future global trading environment.

With the uncertainty over the position of the US economic cycle and trade policy, confidence (especially business confidence) appears more fragile than a year ago. The 'standard' risks around our central GDP growth forecast are shown in figure 9. Despite the downside risks, the potential for loosening monetary policy more than expected, the continued high level of employment and the possibility of a positive trade agreement with China create potential upside risks to the forecast. 


\section{Canada}

The Canadian economy performed better than we had expected in the second quarter, with GDP growth reaching 0.9 per cent, after the low growth rate of 0.1 per cent in the previous two quarters. Net exports made a dominant contribution following a terms of trade improvement of 2.4 per cent in the first quarter and an increase in average oil prices in the second quarter. The increase in export volume was broad-based: energy products up 5.9 per cent, farm and fishing products up 15.2 per cent, non-metallic minerals up 19.0 per cent, aircraft and related engines and parts up 10 per cent and travel services up 2.4 per cent. The strong performance of the export sector more than compensated for a decline in domestic demand, leading to the level of GDP being only 1.6 per cent higher than in the second quarter of 2018 , lower than the 2.3 per cent increase achieved by the US over the same period. We expect that this improvement in quarterly GDP growth will prove to be temporary and forecast annual average GDP growth of about $1 \frac{1}{2}$ per cent in 2019 and about 13/4 per cent in 2020 (as shown in figure 10), slightly lower than the 1.9 per cent achieved in 2018.

Household consumption grew in the second quarter of 2019 by only 0.1 per cent despite real personal disposable income growing by 0.7 per cent. In light of real income gains, we expect domestic demand to be supported by a rebound in consumption, with consumption growing by about $1 \frac{1}{2}$ per cent in 2019 and $1 \frac{3}{4}$ per cent in 2020, after 2.1 per cent in 2018 .

Figure 10. Canada: GDP growth and inflation

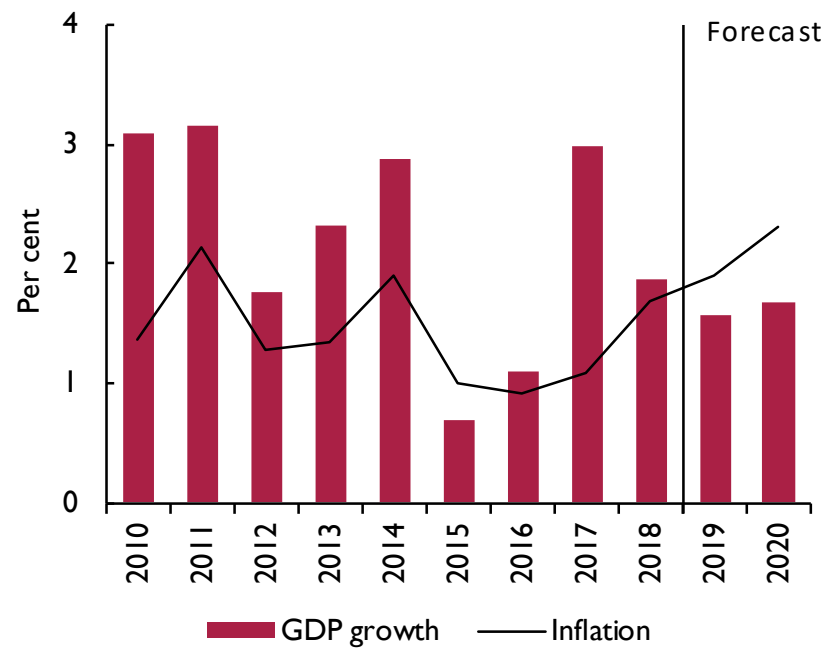

Source: NiGEM database and NIESR forecast.
Headline consumer price inflation has hovered around 2 per cent from June to August, while core inflation (excluding gasoline) has been higher, at around $2 \frac{1}{2} 2$ per cent over the same period. The difference is explained by the fact that gasoline prices fell by 10.2 per cent in the twelve months to August. In the context of inflation being around or above its target of 2 per cent, we expect the Bank of Canada to keep its interest rate at $13 / 4$ per cent until the end of the year, only following the US reductions with a lag.

\section{Euro Area}

The strong pace of economic growth in the Euro Area in 2017, when GDP grew by around $2 \frac{1}{2}$ per cent, has not been sustained. GDP growth slowed to 1.9 per cent last year, with a marked slowing in the second half of the year. Both Germany and Italy saw quarters during which GDP fell in that period. The economic news so far this year has continued existing trends. Industrial production, in particular, has failed to recover, with a rise in the first quarter being more than offset by another fall in the second quarter and the monthly survey indicators continue to show declines in manufacturing order books and consumer confidence. As a consequence, Germany recorded a fall in GDP in the second quarter (the second quarterly fall in a year) and GDP in Italy rose by just 0.1 per cent in both the first and second quarters of this year. For the Euro Area, GDP rose by 0.4 per cent in the first quarter but by just 0.2 per cent in the second, matching the slow growth rate recorded in the third quarter of last year.

Although industrial production has dropped, service sector activity has held up relatively steadily and generally labour market indicators have not suffered. The unemployment rate in the Euro Area at 8.2 per cent in 2018 was the lowest since 2008 and down from 12 per cent in 2013. It has fallen further this year, reaching 7.4 per cent in August, an 11-year low. As a consequence of lower unemployment and, in some countries, rising real incomes, consumer spending growth has continued to support overall economic growth. Household spending has continued to make a steady contribution to GDP growth, as shown in figure 11. At the same time, investment has been adversely affected by increased uncertainty about tariffs and trade. One particular area here is the car industry, with German output and exports being particularly affected (Kara et al., 2019). While the Euro Area has been adversely affected by the decline in global trade, it is also being specifically affected by US tariff actions and the recent WTO ruling about EU support for Airbus is a further issue relevant for trade uncertainty. 


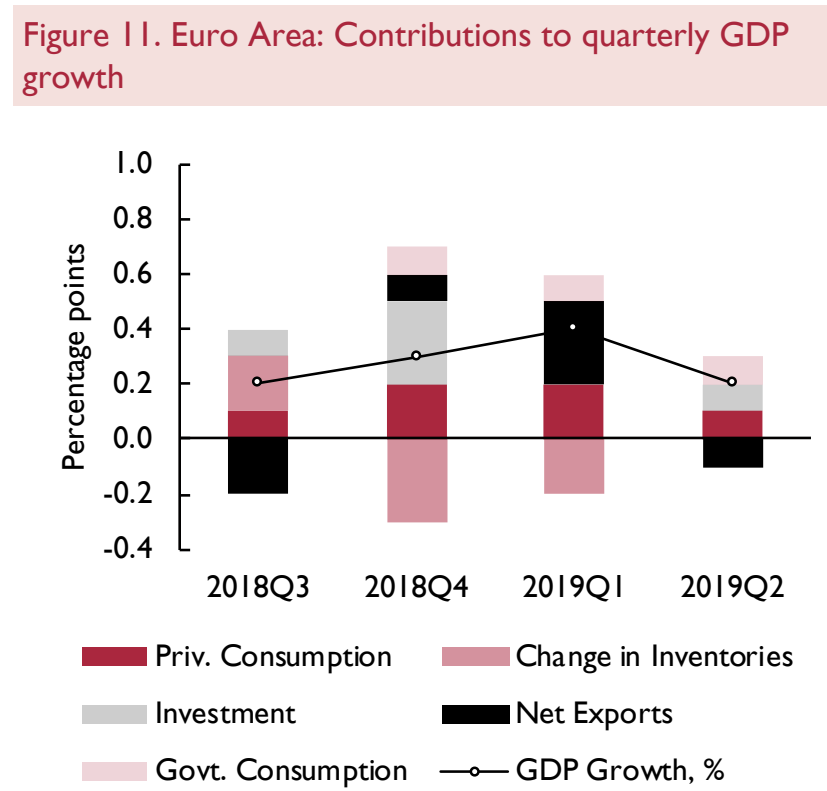

Source: Eurostat.

Inflation (HICP) in September was just 0.8 per cent, having fallen from 1.4 per cent six months and 2.1 per cent a year earlier. With a downturn in economic growth and inflation well below its target, the European Central Bank (ECB) responded in September by reducing the deposit rate by 0.1 percentage points to -0.5 per cent and renewing quantitative easing. At the September ECB monetary policy press conference, the ECB President, Mario Draghi, drew attention to the potential role for fiscal policy to boost output and inflation.

The ECB policy changes should help to firm confidence and are part of a wider monetary easing by the major advanced economies. But with the difficulties in manufacturing industry reflecting wider issues such as uncertainty over tariffs and the world trade growth pattern, our forecast does not anticipate the weakness in output growth in the Euro Area vanishing quickly. Uncertainty over US tariff policy with respect to European motor vehicles may be an additional concern.

Our forecast does not anticipate the ECB's recent policy actions having an immediate major boost. With very slow growth in the first half of the year, industrial production still falling and growth in the service sector slowing, GDP growth this year is forecast to be 1 per cent, the slowest since 2013. Our forecast does not assume that a fiscal boost is forthcoming, and so GDP growth in 2020 is also expected to be around 1 per cent. Inflation, too, is expected remain substantially below the 2 per cent target.
The downside risks to the forecast primarily arise from international factors - tariffs and the global slowdown reducing export growth - although there are risks of spillovers into domestic economies through (lack of) confidence effects. Upside risks come from the potential for a boost from fiscal policy (most likely from individual governments rather than a coordinated response) or from the $\mathrm{ECB}$, which will soon have a new President, loosening its monetary policy stance further. In this case longer-term bond yields could fall further. Into the medium-term, the slower annual rate of productivity growth is expected to continue and, along with prospective demographic trends, points to annual growth in the Euro Area being below 11/2 per cent a year.

\section{Germany}

Our forecast for German GDP growth for 2019 and 2020 has been revised lower. The German economy performed poorly in the second quarter of 2019 with GDP falling by 0.1 per cent, which was in line with our forecast for the quarter. To place this in context, German GDP growth has slowed sharply over the past one and a half years, with annual growth in the second quarter of 2019 at just 0.4 per cent, the lowest since the start of 2013 (as shown in figure 12), and the economy is now among the weakest performers in the Euro Area. There is a chance that the economy will suffer a technical recession, with some lead indicators suggesting that GDP could fall in the third quarter of this year. There are several global

Figure 12. Germany: Components of annual economic growth

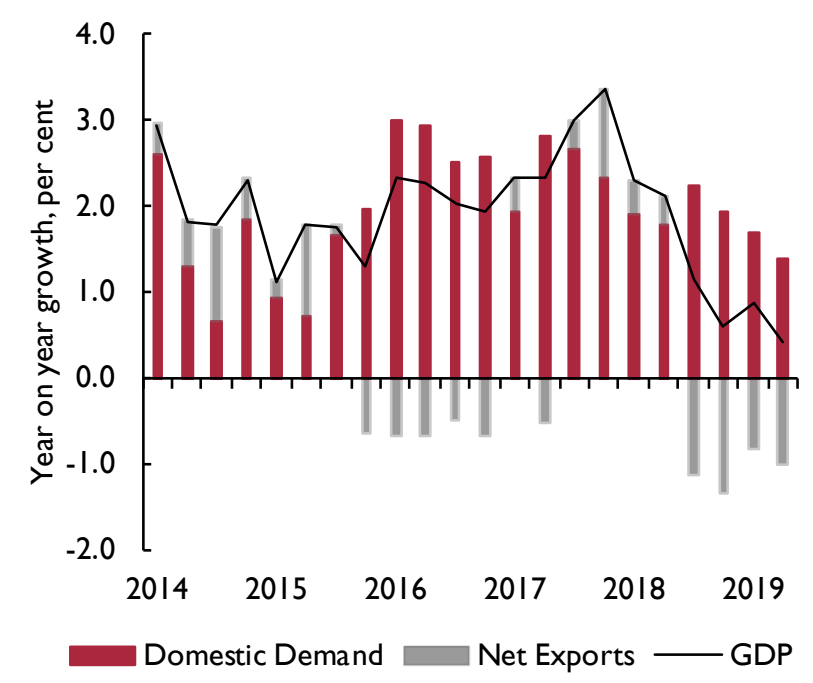

Source: NiGEM database. 
factors that can explain this weakness, including trade disputes, the intensification of Brexit uncertainty and the slowdown in Turkey, falling demand for capital goods and structural changes in the automobile sector. German economic prospects will depend on the evolution of these factors and the role that fiscal policy plays to offset weakness in global demand.

The German economy still, however, has somewhat of a mixed picture. The manufacturing sector, which is heavily exposed to export demand, is suffering a recession and that weakness appears to be spilling over into investment spending and the services sector. Consumer spending, by contrast, remains healthy as households continue to benefit from robust wage growth, fiscal transfers and high levels of employment. Household spending is expected to remain an important driver of economic growth in 2019 and 2020 and is likely to support services sector output as well as the construction sector.

Investment spending was growing at a solid pace up until the middle of this year. In our August forecast we expected investment spending to ease in response to the weakness in activity and the emergence of spare capacity in the manufacturing sector. However, business investment fell by more than we had expected in the second quarter. Looking ahead, we expect investment spending to ease in the medium term.

The labour market continues to remain tight but the slowdown in activity is having a noticeable impact on employment in the industrial sector although employment in the service sector continues to expand. The labour market is particularly tight in the construction sector which is acting as a constraint on public sector infrastructure spending. Wage growth is expected to remain elevated in 2019 and we envisage a further expansion in employment in 2019. The expansion will be modest mainly because of slower economic growth but also because the labour force will start to shrink.

The rise in wages comes during a period when labour productivity is falling. On our measure, German labour productivity, measured in hours, rose by 0.6 per cent in the four quarters to the second quarter of 2019 and unit total costs by 2.1 per cent for the same period, the highest since early 2013. We expect unit total costs to remain at these elevated levels over the forecast horizon.

Headline inflation eased from a recent peak of 2.2 per cent in the third quarter of 2018 to an average of 1.6 in the second quarter of this year. We expect inflation to remain close to 1.5 per cent for the rest of 2019 and 2020 as domestic inflationary pressures are offset by slower energy price rises.

\section{France}

The French economy is expanding at a moderate pace and we expect GDP to grow in 2019 by $1 \frac{1}{4}$ per cent and at a faster pace in 2020 , at a rate close to the 1.7 per cent achieved in 2018. Household consumption and business investments are holding up while manufacturing activity is slowing down.

As we described in the August Review, households' income currently benefits from a fiscal stimulus amounting to about 0.4 per cent of GDP in 2019. In particular, the council tax is planned to decrease in the fourth quarter of this year. We forecast real personal disposable income to increase by about $2 \frac{1}{2}$ per cent in 2019, up from 1.2 per cent in 2018.

Unlike many advanced economies, France still has significant slack in its labour market. The unemployment rate declined in the second quarter by 0.2 percentage points to reach 8.5 per cent. Despite being on a declining trend, the French unemployment rate was still 1.2 percentage points higher than at the trough of 2008 . Figure 13 shows the changes in unemployment rates for different age groups. Since 2015, the unemployment rate

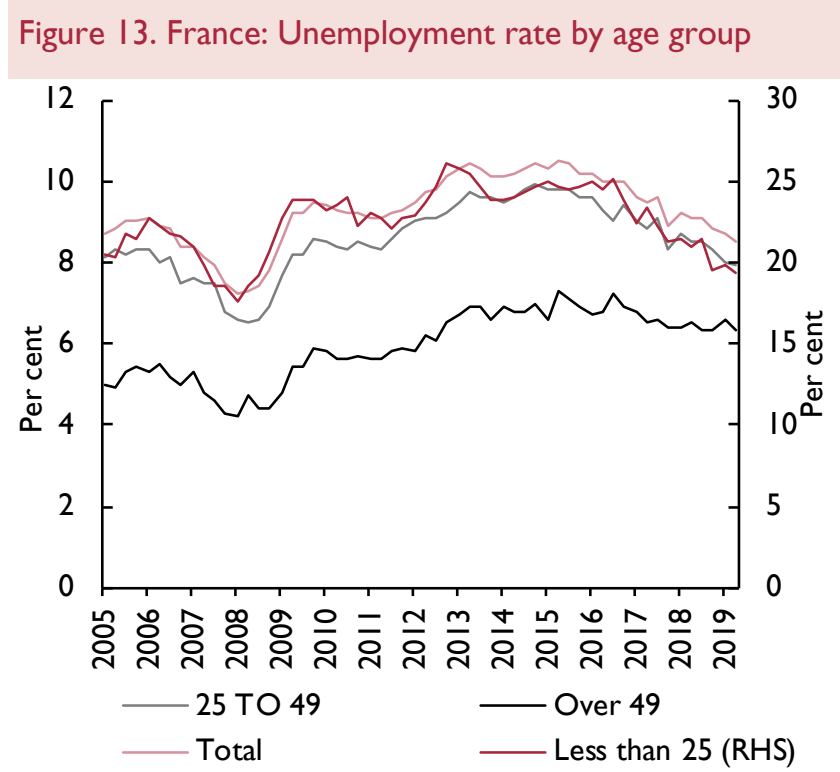

Source: INSEE, NiGEM database. 
of young people (less than 25 years old) has declined faster than that of older people (more than 49 years old). The unemployment rate of young people is at 18.6 per cent - still 1.6 percentage points higher than the trough of 2008 .

The French economy benefits from a very accommodative monetary policy that is spurring investment. Given low ECB interest rates and quantitative easing, French 10-year Treasury bonds traded in the third quarter at an average yield of about -0.2 per cent. This may have boosted investment and, in the second quarter, fixed investment by businesses and government entities increased by 3.7 per cent and 3.8 per cent respectively compared to a year ago. The housing market was a bit less buoyant as housing investment increased by 0.9 per cent over the same period.

However, the robust business investment growth masks headwinds in the manufacturing sector. Manufacturing output declined in the last three months to August by 1.2 per cent compared to the previous three months. Looking forward, businesses seem to be rather pessimistic, as evidenced by the September Banque de France survey - the business sentiment indicator stood at 96, below the long-term average of 100 . The slowdown in manufacturing appears to be driven by international factors more than by domestic factors.

Consumer price inflation in September was 1.1 per cent, with food prices increasing by 2.1 per cent, services prices by 1.3 per cent but manufactured products prices decreased by 0.7 per cent. We forecast inflation to average about $1 \frac{1}{2} 2$ per cent in 2019 and 2020 .

\section{Italy}

There have been two important developments in Italy since our last forecast update in August.

Italy has a new coalition government that includes the centre-left Democratic party and the Five Star movement. The new government has established a more cordial relationship with the European Commission, especially in relation to the fiscal deficit targets, but the task of achieving the 2.04 per cent deficit target set for this year remains challenging.

The second development relates to borrowing costs of the Italian government which have fallen sharply since August because the spread over the analogous German bond has narrowed as political risks have eased and also because sovereign bond yields across developed nations have fallen. The benchmark 10-year bond yield
Figure 14. Italy: GDP growth and inflation

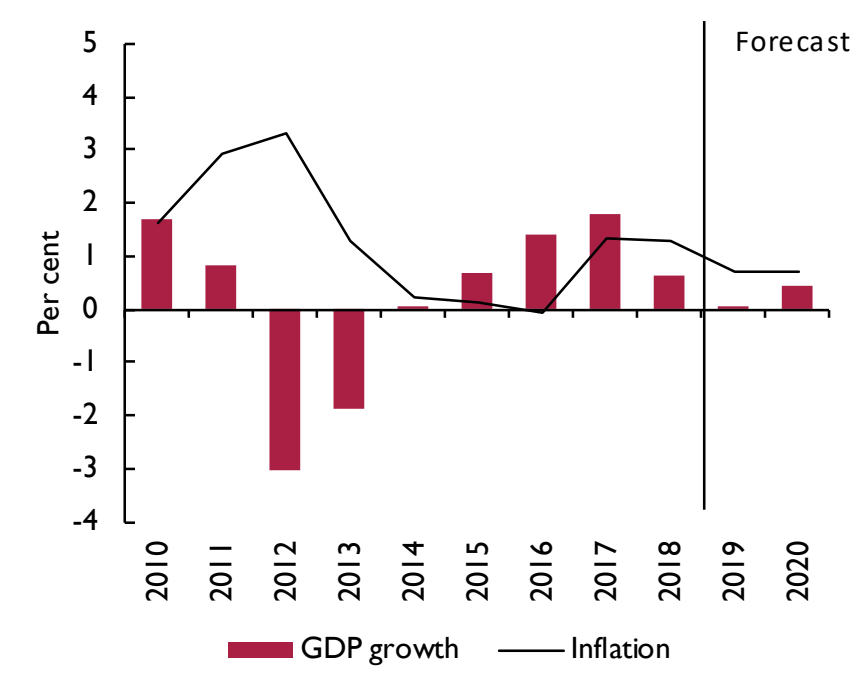

Source: NiGEM database and NIESR forecast.

Note: Inflation is based on HICP.

has dropped to less than 1 per cent and the 2-year government bond is hovering in negative territory at around -0.16 per cent at early October. This time last year the European Commission had rejected the Italian government's budget proposals and the 10-year bond yield rose above 3.5 per cent. According to the Italian government's latest projections, the average borrowing costs for the government will ease from 3.6 per cent to 3.3 per cent next year, which amounts to a saving of $€ 7$ billion.

Italian GDP growth has more-or-less stagnated over the past year because of the domestic political uncertainty as well as the deceleration in global trade. Figure 14 shows the decline in growth. We expect the third quarter of this year to be a trough as the economy starts to benefit from lower borrowing costs and also from the gentle global recovery that is built into our forecasts.

The headline annual inflation rate has eased since the start of this year and has fallen to just 0.4 per cent in the third quarter of this year. Looking ahead, we expect inflation to rise to over 1 per cent in the medium term. 


\section{Spain}

TheSpanisheconomy is expected tocontinue its expansionary phase over the medium-term forecast horizon, supported by the continued accommodative stance of monetary policy. Economic growth will continue to be based on domestic demand, though its positive impact is expected to be weaker than in the recent past. Accordingly, our forecast suggests that GDP will grow by 2 per cent in 2019 and 13/4 per cent in 2020, as shown in figure 15 .

The slower GDP growth outlook will translate into a gradual moderation in the pace of job creation. However, the increase in employment will mean that unemployment will continue to decline, though not as sharply as we anticipated in our previous forecast. The unemployment rate is now expected to decline to 14 per cent this year, with a further fall close to 13 per cent anticipated for 2020. The gradual fall in unemployment along with the expansionary monetary policy stance is expected to translate into upward pressures on prices. We expect harmonised consumer price inflation to rise gradually from $3 / 4$ per cent in 2019 to $1 \frac{1 / 4}{4}$ per cent in 2020.

The two main risks for the Spanish economy are weaker global activity and domestic uncertainty. The possibility that the recent weakness of global activity will be more persistent than anticipated and that protectionist measures will be adopted globally provide a source of uncertainty. Domestically, there is uncertainty surrounding the future direction of economic policies, particularly regarding the process of fiscal consolidation - with Spanish government finances remaining vulnerable to adverse shocks.

Figure 15. Spain: GDP growth and inflation

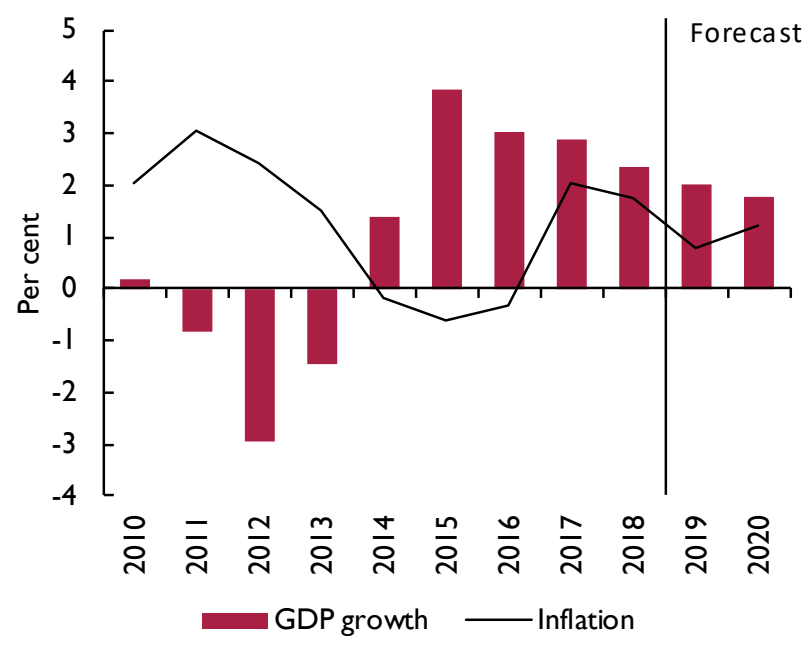

Source: NiGEM database and NIESR forecast.

Note: Inflation is based on HICP.

\section{Japan}

Japan's economy grew by 0.3 per cent in the second quarter of 2019 and maintained its moderate expansion from the fourth quarter of 2018 (see figure 16). Japan's GDP growth rate was revised down, with slower investment growth and a 3 per cent decrease in yearon-year exports in the second quarter of 2019. Imports fell by less, edging down in the second quarter by 0.3 per cent year-on-year, reflecting resilience in Japanese domestic demand. Meanwhile, the core inflation rate in Japan was at 0.3 per cent in August, well below the Bank of Japan's 2 per cent inflation target.

One of the biggest downside risks to the Japanese economy is the rise in the consumption tax from 8 per cent to 10 per cent in October. While domestic demand growth has supported the moderate economic expansion, it is likely to be adversely impacted by the 2 percentage point hike. After the consumption tax hike in 2014, Japan's GDP contracted for two quarters between April and September 2014 (Liadze and Piggott, 2019). Japan's economy may be dealt a similar blow but the authorities are providing supportive monetary and fiscal measures.

Japan's economy is facing other uncertainties. The ongoing US-China trade war and the Japan-South Korea trade disputes from this July put further downward pressure on exports. Besides the worsening trade protectionism, the weakness in the global economy and a five-year low in consumer confidence in August also point to a further slowdown. Meanwhile, Japan has

Figure 16. Japan: Quarterly year-on-year GDP growth rate

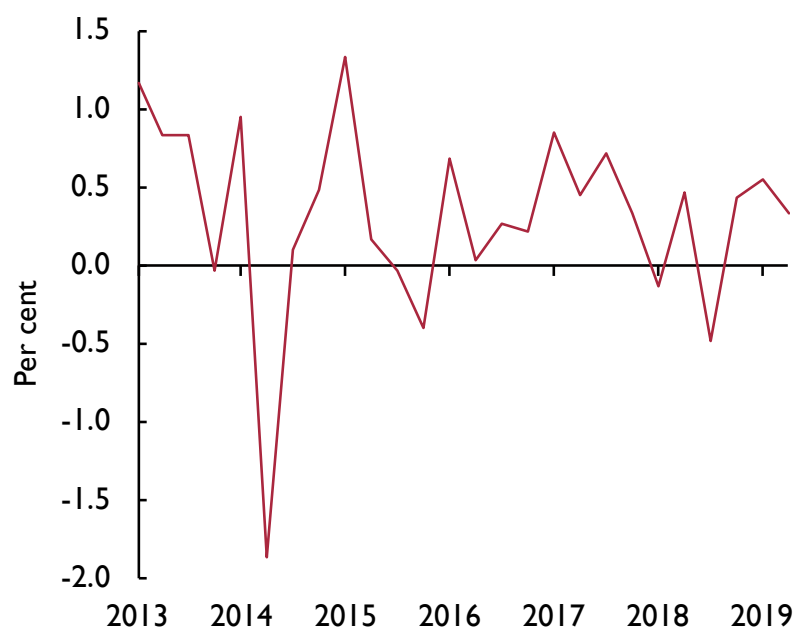

Source: NiGEM database and Bank of Japan. 
just experienced Typhoon Hagibis, the strongest for half a century, with its cost yet to be calculated.

On the other side, there are some positive signs in the Japanese economy. The unemployment rate was at a near three-decade low in July and the services sector grew steadily to support the economy in the first half of 2019. The ongoing projects related to the 2020 Tokyo Olympics are expected to boost the economy in near future.

Overall, we expect Japan's economy to grow by about 1 per cent in 2019 and maintain our previous projection that there will be only very low growth in GDP in 2020, largely reflecting the consumption tax increase. Japan's economic conditions in 2020 can be improved if there are accommodative monetary policies from the Bank of Japan, and fiscal counter-measures to avoid a negative impact from the consumption tax hike.

During the Bank of Japan meeting this September, the Japanese monetary authorities held policy unchanged. But Japan's year-on-year consumer price inflation fell to 0.2 per cent in September 2019, reversing the upward trend observed in the first months of this year. Although the consumption tax will increase inflation, the chance of a further monetary stimulus has increased, especially if the underlying inflation rate is still as far away from the 2 per cent target and if general economic conditions fail to improve in the last months of 2019.

We forecast Japan's inflation to be around $1 / 2$ per cent in 2019 and 2 per cent in 2020, with the increase reflecting the likely pass-through effects of the tax hike on the consumption prices.

\section{China}

Growth in the Chinese economy in 2019 continued its gradual deceleration in every quarter from the start of 2018, reaching 6 per cent year-on-year in the third quarter of 2019, the slowest rate of growth since 1990, as illustrated in figure 17.

The trade talks between China and the US continued their uncertain pattern in the third quarter of 2019, with the trade uncertainties and global economic slowdown putting further downward pressure on China's economy. After a 1 per cent year-on-year fall in exports from China this August, exports contracted by 3 per cent yearon-year in September. To offset the negative impact of the global trade tensions and economic slowdown, in August the People's Bank of China allowed the Yuan rate
Figure 17. China: GDP growth

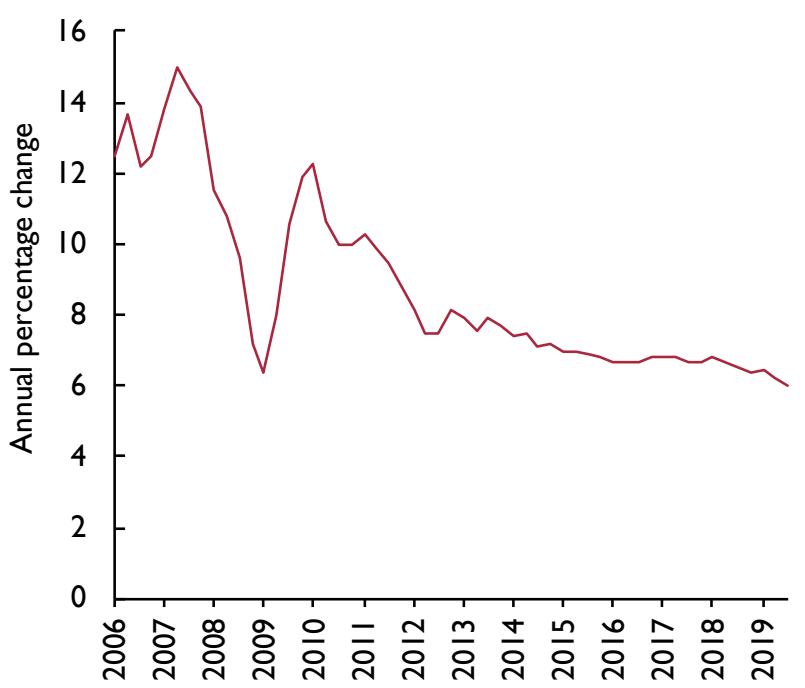

Source: NiGEM database

Figure 18. China: Yuan to US dollar exchange rate

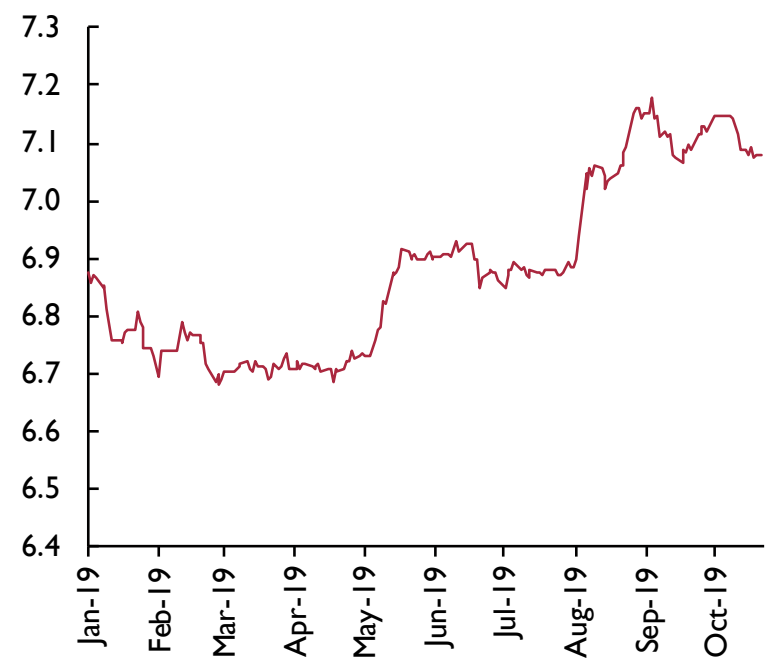

Source: St Louis Federal Reserve (FRED database).

against the US dollar to depreciate and breach 7 for the first time since 2008. Even with the US labelling China as a 'currency manipulator', the Yuan-Dollar exchange rate has stayed above 7 ever since, as shown in figure 18 .

There were also potentially worrying signs shown in figures for China's industrial production and automobile sales. China's industrial production grew by 4.4 per cent (year-on-year) in August, down from 4.8 per cent 
in July, and monthly car sales in China continued their 15-month decline with a 5.2 per cent fall in September.

On the upside, both retail sales and the service industry held up well in the second quarter of 2019 and the Caixin China General Manufacturing PMI continued its upward trend from May 2019. It has stayed in the expansion zone since August, rising to 51.4 per cent in September. Despite reduced overseas sales, new orders increased at the fastest pace since March 2018 and the employment rate was unchanged between August and September.

We remain cautiously optimistic about continued growth in China's economy and forecast China's annual GDP growth rate in 2019 and 2020 at $61 / 4$ per cent and 53/4 per cent respectively. China's economy still faces the impact of the global economic slowdown. While the 13th USChina trade talks finally concluded with a phase-one deal in early October, worries over the final negotiation outcomes persist. Meanwhile, the orderly depreciation of the Yuan could provide some support to exports; and the ongoing infrastructure spending and tax-cuts are stimulating the construction and manufacturing sectors.

China's CPI inflation rate increased to 2.8 per cent in both July and August 2019, the highest rate from early 2018, and 3 per cent in September, the highest rate since 2013. China's inflation was driven by higher wholesale prices of agricultural products, especially the soaring pork prices amidst the widespread African swine fever.

With measures improving the supply of agricultural products, we expect China's inflation rate to stabilise at 21/2 per cent for both 2019 and 2020.

There is likely to be potential for supportive fiscal and monetary policy changes in the coming months should Chinese economic conditions deteriorate. With overall financial risks appearing to be contained, there is room for the Chinese authorities to cut rates following other central banks and conduct fiscal stimulus, with further tax reductions and more spending on infrastructure projects.

\section{India}

The Indian economy is facing a severe demand slowdown and liquidity crisis which has culminated in the annual GDP growth rate falling to a six-year low of 5 per cent in the second quarter of this year. The output of the automotive industry - which contributes more than 7 per cent to India's GDP - has experienced a sharp decline, and output fell for a 10th consecutive month in August. Against this background, we expect the economy to grow by a subdued 6 per cent in 2019, and only at a marginally higher rate in 2020, as shown in figure 19.

The finance ministry cut the headline corporate tax rate to 22 per cent from 30 per cent to boost manufacturing and revive growth. The fiscal stimulus is expected to help attract private investment, improve competitiveness, and reduce the high levels of unemployment. However, the risk that India will not meet its fiscal deficit target of 3.3 per cent has increased significantly as tax revenue is already quite weak.

Inflation rose to 3 per cent year-on-year in the second quarter, and the latest monthly data indicate a further pickup, though inflation remains well below the central bank's target of 4 per cent. The Reserve Bank of India reduced the policy rate by 25 basis points in October, having already implemented an unconventional 35 basis points reduction in September. Over the short term, continued low inflation should allow the Reserve Bank to maintain its accommodative policy stance. In line with this, our forecast suggests inflation will remain below target in 2019 and 2020.

Figure 19. India: GDP growth and inflation

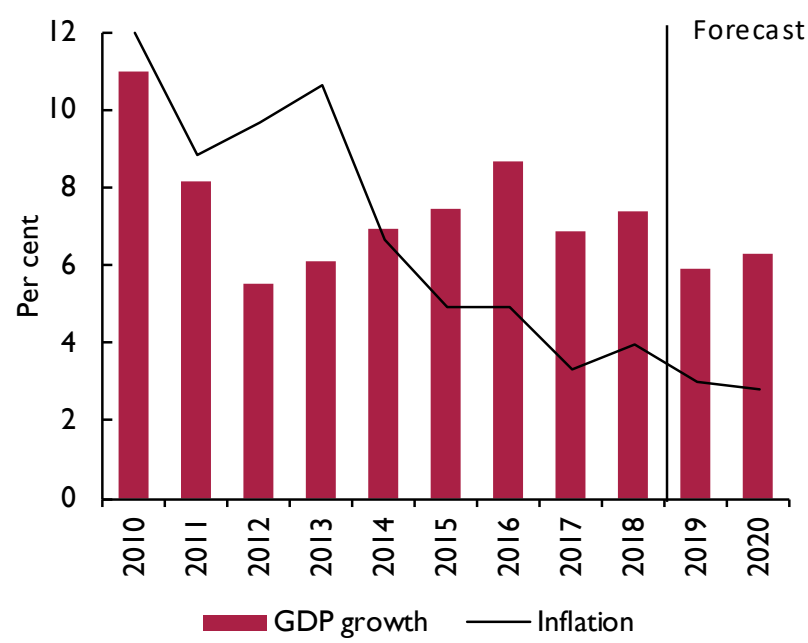

Source: NiGEM database and NIESR forecast.

Note: Inflation is based on CPI. 


\section{Brazil}

Brazil narrowly avoided a technical recession when GDP grew by 0.4 per cent quarter-on-quarter in the three months to June, supported by better than expected growth in the industrial sector. Going forward, the economy will also benefit from recent cuts in the policy rate that lowered the Selic to a historic low of 5.5 per cent, as shown in figure 20. The Monetary Policy Committee (Copom) believes that inflation expectations are wellanchored and that underlying inflation, including the components most sensitive to the business cycle and monetary policy, is running at reasonable levels. We believe that Copom could cut the policy rate by an additional 50 basis points in the final quarter of this year to provide more monetary policy stimulus following dovish statements made by the US Federal Reserve.

The prospect of impending pension reform continues to dominate media headlines and has an important impact on forecasts for GDP growth going forward. Indeed, many investors are reported to have opted to postpone investment decisions until the reform passes. The Business Confidence Index (BCI), compiled by the Brazilian National Confederation of Industry, suggests that the pension reform process has had an important impact on business confidence; despite initial legislative delays, Brazil's lower house approved the bill in August, and it passed the first of two floor votes in Senate on 2 October. The BCI improved to 59.4 index points in September and will likely improve further following Senate approval of the bill. Although the final bill

Figure 20. Brazil: Selic interest rate (\%)

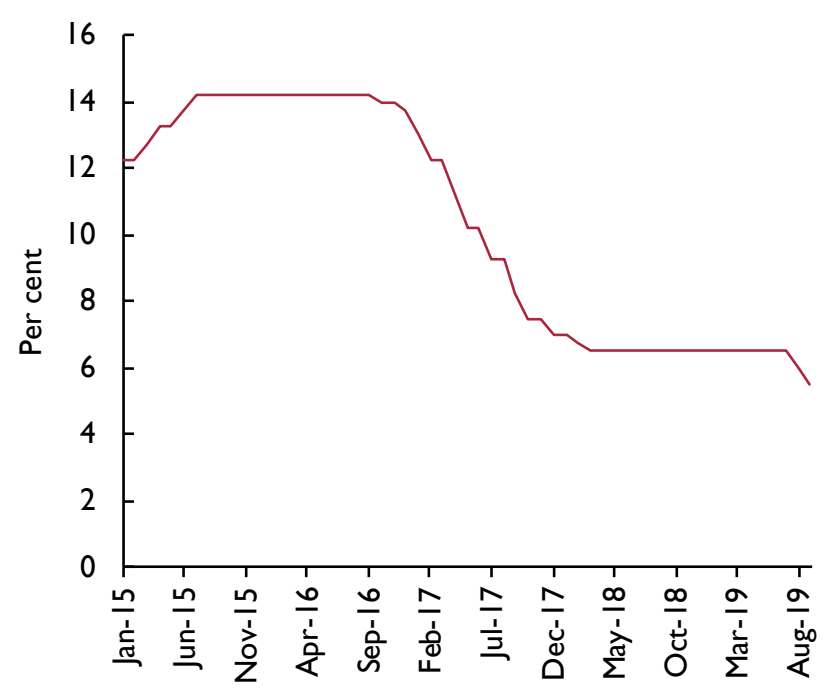

Source: Banco Central do Brasil. will likely be a diluted version proposed by Economy Minister Paulo Guedes, it will signal to investors that President Bolsonaro is committed to an agenda of market liberalisation, deregulation and privatisation that Brazil's economy needs to ensure long-term sustainability.

Earlier this year, the Central Bank of Brazil (BCB) cut its GDP growth forecast from 2 per cent to 0.8 per cent for 2019, similar to the market consensus estimates for economic growth for the year. We are forecasting GDP growth of $3 / 4$ per cent for this year, with growth improving to almost $13 / 4$ per cent in 2020 , with these forecasts contingent on the success of the pension reform and ongoing fiscal consolidation.

\section{Russia}

Higher global oil prices since the low point in early 2016 have helped the Russian economy to return to growth and, after growth of 1.6 per cent in 2017 , the economy grew by 2.3 per cent in 2018 - the fastest rate since 2012. The robust GDP growth was supported by strong consumption growth of 2.0 per cent year-on-year as consumers front-loaded consumption in anticipation of the increase in VAT to 20 per cent (from 18 per cent) in January 2019.

The first half of 2019 showed a deceleration in GDP growth to 0.7 per cent year-on-year as the high base effect from the 2018 World Cup and the contractionary VAT rise took hold. Our expectation is that growth

Figure 21. Russia: GDP growth and inflation

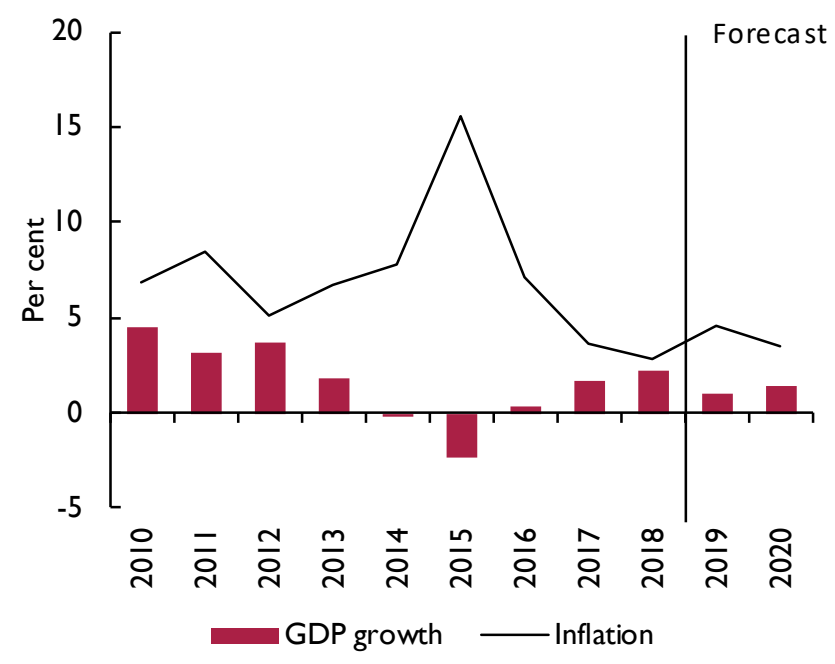

Source: NiGEM database and NIESR forecast.

Note: Inflation is based on CPI. 
will remain weak in 2019 at around 1 per cent before recovering in 2020 to $1 \frac{1}{2}$ per cent, as shown in figure 21 .

The slowdown in 2019 has been broad based. Wholesale and retail trade contracted in Q1 as the VAT increases dented demand whilst at the same time industrial output disappointed. Weather-related European weak demand for natural resources also depressed activity. The recent OPEC+ meeting concluding on 2 July ratified the production constraints on oil, taking the production constraints into 2020. However, the budgeted increase associated with the 'national project' in public sector investment spending is likely to feed through, and so give a boost to output growth in 2020 relative to this year.

Consumer price inflation has been below the 4 per cent target level during 2018 but increased to above 5 per cent in the first quarter of 2019 as the effect of the VAT increase passed through. The broad-based deceleration and benign oil prices appear in the inflation data, weakening from 5.1 per cent in May to 4 per cent in September. After raising policy interest rates from 7.25 per cent to 7.50 per cent in September last year and again in December to 7.75 per cent, where they held them until the June meeting, the central bank reduced its policy rate to 7.5 per cent before two further cuts in July and September, taking the rate to 7.0 per cent. Further rate cuts are expected in the final quarter of this year. Our inflation forecast has been revised downwards to slightly undershoot the central bank 4.0 per cent target next year.

\section{Australia}

The Reserve Bank of Australia (RBA) lowered the main policy rate, called the cash rate, by 25 basis points on 1 October to 0.75 per cent. With this reduction, the Reserve Bank Board has halved the cash rate since May this year. The most proximate reason for the decision to lower the policy rate is the downside risk to the global economic outlook, which is attributable to the disputes between the US and China, which could adversely affect the Australian economy. We expect slower growth this year than last, as shown in figure 22.

According to official statistics, the Australian economy has expanded by 0.5 per cent in the first and second quarters of this year. This marks something of a pick-up compared with the previous six months when quarterly growth averaged just 0.2 per cent. Details of the national accounts data suggest that the recovery in GDP growth this year has been led by exports and fiscal measures.
Figure 22. Australia: GDP growth and inflation

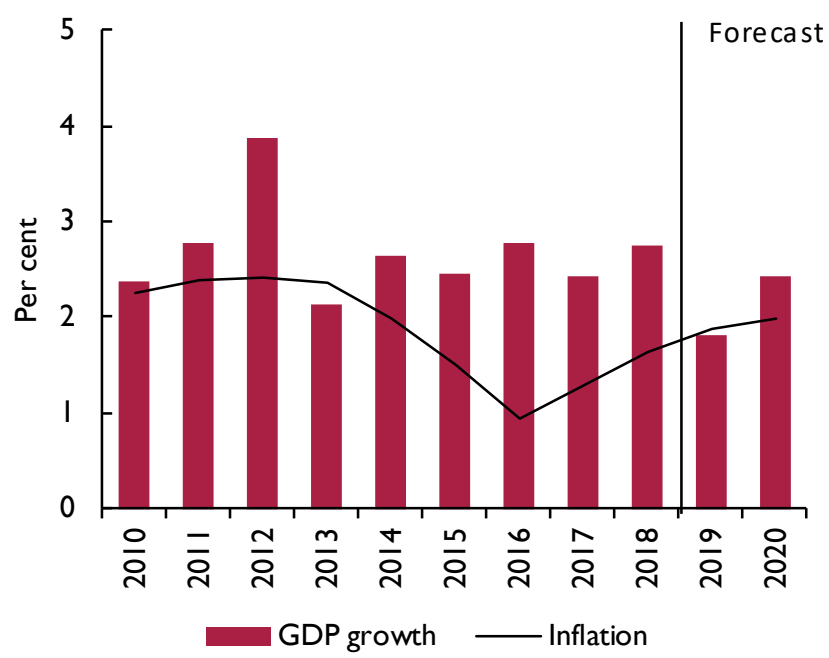

Source: NiGEM database and NIESR forecast.

Note: Inflation is based on consumer expenditure deflator.

The labour market paints a mixed picture. Employment continues to expand at a rapid pace, but wage growth remains subdued. The strength in employment has been met by rising participation levels such that the unemployment rate has remained steady around 5.25 per cent. Although the unemployment rate has been falling steadily since late-2014, the current level remains well above the 4.1 per cent trough achieved in early 2008 , suggesting that there is room for a further increase in employment.

At 1.6 per cent, annual inflation continues to remain below the target rate of $2-3$ per cent. The relatively low inflation outturns registered recently are consistent with subdued levels of wage inflation. Low inflationary pressures combined with a downside risk to the global economic outlook have encouraged the RBA board to signal that the official cash rate will remain low for an extended period of time. 


\section{NOTES}

I "Patient" was the description used by Jerome Powell, Chairman of the Federal Reserve in a speech on 8 March.

2 The 10-year Treasury yield has fallen from 3.2 per cent in midOctober 2018 to 1.76 per cent on II October.

3 The Vix index is seen as a barometer of investor sentiment and market volatility and is a measure of market expectations of uncertain volatility implied by S\&P 500 index option prices.

4 Bloomberg reported on 3 July that "[President] Trump tweeted that Europe and China are playing a "big currency manipulation game"', https:/www.bloomberg.com/news/articles/2019-07-03/ be-prepared-for-anything-as-trump-slams-europe-china-on-tax.

5 At 20 I I PPP weights.

\section{REFERENCES}

Caldara, D., Prestipino, A., lacoviello, M., Molligo, P. and Raffo, A. (2019), 'The economic effects of trade policy uncertainty', International Finance Discussion Papers No. 1256, Board of Governors of the Federal Reserve System.

Carreras, O. and Kirby, S. (2016), "Is the global trade slowdown a risk to our forecast outlook?', National Institute Economic Review, 235, February, FI4-I5.

Chadha, J.S. (2018), 'The international economy: bind or boon?', National Institute Economic Review, 246, November, R50-63.

Constantinescu, C., Mattoo, A. and Ruta, M. (20I4), 'Slow trade', Finance \& Development, $5 \mathrm{I}(4)$.

Draghi, M. (2019), 'Introductory statement to the press conference (with Q\&A)', 12 September.

Hantzsche, A. and Liadze, I. (20I8), 'The war on trade: beggar thy neighbour - beggar thyself?', National Institute Economic Review, 244, May.

Hurst, I. and Liadze, I. (2019), 'Fiscal stimulus in China to boost global growth', National Institute Economic Review, 248, May.
Kara, A. and Liadze, I. (2019), 'The textbook response: using Chinese fiscal policy to offset US tariffs', NIESR blog, 2 May.

Kara, A., Liadze, I. and Paczos, M. (2019), 'The impact of a tariff on automobiles', National Institute Economic Review, 249, August, F52-54.

Lennard, J. and Theodoridis, K. (2018), 'Oil and the macro economy', National Institute Economic Review, 243, February, F48-9.

Lenoel, C. (2018), 'Predicting recessions in the United States with the yield curve', National Institute Economic Review, 244, May.

-(2019), 'Is the US yield curve signalling that a recession is on the way?', National Institute Economic Review, 248, May.

Liadze, I. (2018), 'Trade wars - the saga continues', National Institute Economic Review, 246, November.

Liadze, I. and Hacche, G. (20I7), 'The macroeconomic implications of increasing tariffs on US imports', NiGEM Observations, No 12.

Liadze, I. and Naisbitt, B (20I8), 'Global spillover effects of US monetary tightening', National Institute Economic Review, 246, November, F42-3.

Liadze, I. and Piggott, R. (2019), Japan consumption tax increase', National Institute Economic Review, 247, February, F65.

Naisbitt, B. (2018a), 'The re-emergence of concerns about debt', National Institute Economic Review, 244, May.

-(2018b),'The risks of rising global indebtedness', National Institute Economic Review, 245, August.

-(2019), 'The risks from rising real house prices', National Institute Economic Review, 247, February, F55-57.

Shin, H.S. (2019), 'What is behind the recent slowdown?', Presentation at the 'Public Finance Dialogue' workshop, German Federal Ministry of Finance and Centre for European Policy Research, May 2019.

South China Morning Post (2019), 'US-China trade war presented Vietnam a golden opportunity but can its infrastructure keep up?', 18 September. 